\title{
Peran Ekonomi Kreatif Dalam Prepestif Kesejatraan Masyarakat
}

\author{
Erwan Iskandar \\ Dosen Tetap Fakultas Ekonomi dan Bisnis Islam \\ IAI Al-Azhar Lubuklinggau \\ erwan3645@gmail.com
}

\begin{abstract}
Abstrak: Ekonomi kreatif merupakan suatu bentuk kegiatan manusia yang berkaitan dengan kreatifitas dan inovasi dalam pengembangan sebuah produk. Agar produk yang dihasilkan dapat berkembang dengan baik maka diperlukan suatu menejemen. Manajemen di perlukan untuk mengatur dan mengkoordinasikan faktor-faktor produksi untuk meningkatkan nilai dan benefit dari sebuah produk barang atau jasa yang dihasilkan agar efisien, melalui pemanfaatan pengetahuan dan keterampilan. Jenis penelitian ini adalah penelitian lapangan atau sering dikenal dengan field research. Adapun sifat penelitian yang digunakan adalah deskriptif kualitatif serta dalam penelitian ini menggunakan cara berfikir induktif dengan menggunakan sumber data primer dan sekunder. Teknik pengumpulan data yang digunakan adalah wawancara, observasi dan dokumentasi. Dapat disimpulkan bahwa dengan adanya ekonomi kreatif dapat mengurangi jumlah pengangguran usahan ini juga dapat meningkatkan pendapatan keluarga serta pendapatan masyarakat sekitar.
\end{abstract}

Kata Kunci: Ekonomi Kreatif, Kesejatraan masyarakat

\section{PENDAHULUAN}

Ekonomi kreatif digagas pertama kali di inggris oleh john howkins melalui bukunya creative economy. Menurut Howkins ekonomi kreatif merupakan aktifitas perekonomian yang lebih mengandalkan ide atau gagasan (kreatif) untuk mengelola material yang bersumber dari lingkungan sekitarnya menjadi bernilai tambah ekonomi. Di lihat dari gagasan tersebut, secara realistis-sederhana ekonomi kreatif (creative conomy) diartikan sebagai talenta (ide kreatif-inovatif) dengan nilai ekonomi yang mampu merubah kualitas hidup manusia menjadi lebih sejahtera. Ekonomi kreatif lebih mengandalkan kreativitas individu melalui gagasan, daya kreasi, dan daya cipta untuk meningkatkan nilai tambah ekonomi karyanya, sehingga mampu menciptakan lapangan kerja dan kesejahteraan. 
Konsep ekonomi kreatif merupakan konsep yang di dasarkan pada kemampuan dan ketrampilan manusia. Oleh karena itu bangkitnya gelombang ekonomi baru menuntut inovasi dan kreatifitas masyarakat, sehingga dibutuhkan kualitas sumber daya manusia sebagai pelaku ekonomi kreatif. Kondisi ini di kaitkan dengan kemampuan dalam mengelola potensi local yang ada. Perkembangan ekonomi kreatif tidak terlepas dari perkembangan industri kreatif karena pengembangan ekonomi kreatif membutuhkan dukungan dari industry ekonomi. Perkembangan ekonomi kreatif diyakini sebagai cara bagi Negara berkembang untuk mengikuti perkembangan ekonomi global. Hal ini karena sektor ekonomi kreatif di tempat tertentu sangat bergantung pada kualitas sumber daya manusia serta manajemen yang baik dalam mengembangkan suatu kreatifitas dalam sebuah produk yang diciptakan. Kualitas sumber daya manusia dalam menggali kreativitas sebagai inovasi dorongan utama dalam mengembangkan ekonomi kreatif. Dalam pengembangan ekonomi kreatif akan meningkatkan bisnis yang kompetitif. Perkembangan sector ekonomi kreatif juga harus berorientasi pada aspek budaya masyarakat. Sehingga perkembangan sektor ekonomi yang menguntungkan akan berdampak pada bangkitnya peluang bisnisyang digerakan oleh masyarakat.

Kesejahteraan hidup masyarakat dapat di lihat dari kemampuan financial masyarakat berdasarkan tingkat ekonomi tertentu. Dalam upaya meningkatkan kesejahteraan hidupnya, masyarakat harus bekerja atau berusaha. Masyarakat dengan pendapatan menengah keatas, biasanya dalam memenuhi kebutuhan hidupnya dengan pekerjaan yang menghasilkan pendapatan tinggi seperti membuka usaha yang besar, pegawai pemerintah dan lain sebagainya, sedangkan masyarakat dalam tingkat menengah kebawah biasanya melakukan bisnis atau usaha kecil untuk memenuhi kebutuhan hidupnya.

\section{METODE PENELITIAN}

Penelitian ini juga dianggap sebagai pendekatan luas dalam penelitian kualitatif atau sebagai metode untuk mengumpulkan data penelitian merupakan kegiatan ilmiah yang dilakukan secara sistematis dengan menggunakan metode 
pendekatan tertentu danmemiliki hubungan yang bersifat logis antara sartu bagian dengan bagian lainya dalam memperoleh kebenaran Penelitian ini bersifat deskriptif kualitatif yaitu penelitianyang menggambarkan, meringkas berbagai kondisi, situasi atau fenomena social yang ada di masyarakat dan upaya menarik realita ke permukaan sebagai ciri, karakter, sifat, model, tanda, ataugambaran tentang kondisi, situasi fenomena tertentu.

\section{PEMBAHASAAN DAN LANDASAN TEORI}

\section{Pengertian Ekonomi Kreatif}

Ekonomi Kreatif adalah sebuah konsep di era ekonomi baru yang mengintensifkan informasi dan kreatifitas dengan mengandalkan ide dan keluasaan pengetahuan dari sumber dayamanusia sebagai faktor produksi utama dalam kegiatanekonominya.istilah ekonomi kreatif berkembang dari Modal berbasis kreatifitas yang dapat berpotensi meningkatkan pertumbuhan ekonomi di suatu daerah. Ekonomi kreatif sangat tergantung kepada modal manusia karena ekonomi kreatif membutuhkan sumberdaya manusia yangmampu melahirkan ide dan menerjemahkanya kedalam barang atau jasa yang bernilai ekonomi.

Ekonomi kreatif merupakan aktivitas yang mengandalkan sebuah idedengan menciptakan sebuah kreativitas serta ketrampilan untuk mengembangkan suatu produk yang sudah ada maupun yang belumada untuk dimenjadikan suatu bisnis yang menguntungkan sehinggadapat menambah suatu pendapatan guna meningkatkan perekonomian.

\section{Peran Ekonomi Kreatif}

Ekonomi kreatif berperan dalam perekonomian suatu bangsaterutama dalam menghasilkan pendapatan, menciptakan lapanganpekerjaan, dan meningkatkan penerimaan hasil ekspor, meningkatkan teknologi, menambah kekayaan intelektual dan peran social lainnya.Ekonomi kreatif dipandang sebagai penggerak pertumbuhandan perkembangan ekonomi suatu bangsa. Seperti yang dikemukakanoleh UNCTAD dalam Creative Economy Report bahwa ekonomi kreatif secara potensial berperan dalam menggerakan pertumbuhan ekonomi yang disebabkan oleh hal-hal sebagai berikut; 
a) Ekonomi kreatif dapat mendorong penciptaan pendapatan,lapangan pekerjaan, dan penerimaan ekspor.

b) Ekonomi kreatif memupuk ekonomi, budaya dan aspekaspeksosial yang salin berhubungan dengan teknologi, kekayaan intelektual dan tujuan wisata.

c) Ekonomi kreatif merupakan salah satu pilihan pengembangan yang layak untuk menggugah inovasi.

d) Didalam jantung ekonomi kreatif terdapat industry-industri kreatif.

\section{Pokok-pokok Ekonomi Kreatif}

Kreatif dan inovatif adalah karakteristik personal yang terpatri kuat dalam diri seorang wirausaha. Bisnis yang tidak dilandasi upaya kreatifdan inovativ bisnis tersebut tidak dapat berkembang.50 Selain dari kreatifdan inovatif dalam sebuah wirausaha kita juga membutuhkan sebuah kreasi. Kreasi adalah penciptaan dimana daya kreasi merupakan faktordalam industri kreatif dengan melibatkan banyak hal yang berhubungan dengan cara-cara mendaptkan input, menyimpanya dan mengolahnya. Sehingga daya kreativitas, ketrampilan dan bakat, orisinalitas ide adalah factor suplai yang paling penting. Dengan produk yang unik dan berbeda serta orisinil, produk tersebut mampu berkompetisi dengan produk-produk lawanya dengan lebih baik dan berpotensi menciptakan lapangan kerja.

Terdapat tiga hal pokok yang menjadi dasar dari ekonomi kreatif, antara lain kreativitas, penemuan dan inovasi yaitu;

\section{Kreativitas}

Yaitu suatu kapasitas atau kemampuan untuk menghasilkanatau menciptakan sesuatu yang unik, fresh, dan dapat diterima diumum. Seseorang yang memiliki kreativitas dapat memaksimalkan kemampuan dan dapat menciptakan serta menghasilkan sesuatu yang berguna bagi dirinya sendiri beserta orang lain.

2. Penemuan

Istilah ini menekankan pada penciptaan sesuatu yang belum pernah ada sebelumnya dan dapat diakui sebagai karya yang mempunyai fungsi yang unik atau belum pernah di akui sebelumnya.

3. Inovasi 
Merupakan suatu transformasi dari ide tau gagasan dengan dasar kreativitas dengan memanfaatkan penemuan yang sudah ada untuk menghasilkan suatu produk bernilai tambah dan bermanfaat.

\section{TUJUAN EKONOMI KREATIF DAN RUANG LINGKUP EKONOMI KREATIF}

1. Tujuan

Tujuan ekonomi kreatif adalah meningkatkan kualitas hidup,toleransi, dan menciptakan nilai tambah. Ekonomi kreatif dalam sumberdaya yang ada akan sangat membantu masyarakat untuk mengelola sumber daya yang ada dalam meningkatkan pendapatan atau kesenjangan hidup.

2. Ruang Lingkup Ekonomi Kreatif

Dalam ekonomi kreatif terdapat subsektor ekonomi kreatif, yaitu sebagai berikut;

1) Industri periklanan

2) Industri arsitekstur

3) Industri barang seni

4) Industri kerajinan

5) Industri desain

6) Industri fesyen

7) Industri film

8) Industri permainan interaktif

9) Industri musik

10) Industri seni pertunjukan

11) Industri penerbitan dan percetakan

12) Industri layanan computer dan peranti lunak

13) Industri riset dan pengembangan

14) Industri kuliner

15) Aplikasi dan game developer

KESEJAHTERAAN MASYARAKAT

1) Pengertian kesejahteraan Menurut kamus bahasa Indonesia, 
Kesejahteraan berasaldari kata sejahtera yang berarti aman, sentosa, makmur, dan selamatatau dapat diartikan sebagai kata atau ungkapan yang menujuk padakeadaan yang baik. Dalam arti yang lebih luas kesejahteraan adalah terbebasnya seseorang dari jeratan kemiskinan.54 Sejahtera adalah keadaan yang merujuk kearah yang kebih baik dimana orang-orangdalam keadaan makmur dan damai. Kesejahteraan yang meliputi seluruh bidang kehidupan manusia yaitu mulai dari ekonomi, social,budaya, dan lain sebagainya. Untuk mendapatkan kesejahteraan memang tidak mudah. Tetapi bukan berarti mustahil sebab masihbanyak yang bisa dikerjakan untuk mencapai suatu kesejahteraan. Salah satu indicator kesejahteraan yaitu jumlah dan pemerataan pendapatan, hal ini sangat berhubungan dengan lapangan pekerjaan,kondisi usaha, dan factor ekonomi lainya.

Penyediaan lapangan kerja mutlak dilakukan oleh semua pihak agar masyarakat memiliki pendapatan tetap untuk memenuhi kehidupanya. Tanpa itu semuamustahil manusia mencapai kesejahteraan. Tanda-tanda masih belum sejahteranya suatu kehidupan masyarakat adalah jumlah dan sebaran pendapatan yang mereka terima belum seimbang. Sehingga kesempatan kerja dan berusaha sangat diperlukan agar masyarakat mampu meningkatkan jumlah pendapatan yang mereka terima untuk meningkatkan kesejahteraan.

2) Dalil Kesejahteraan

Dalam al-quran telah menyinggung mengenai kesejahteraanyang terdapat dalam Al-Quran pada surat An-Nahl ayat 97

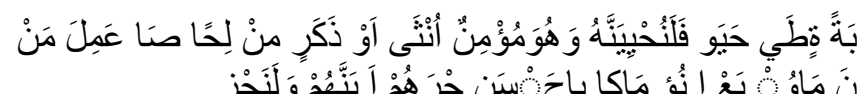

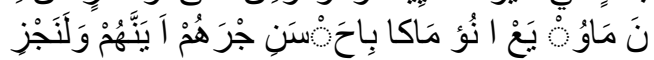
"barang siapa yang mengerjakan amal saleh, baik laki-laki maupun perempuan, maka sesungguhnya akan kami berikan kepadanyakehidupan yang baik sesungguhnya akan kami beri balasan kepada mereka dengan pahala yang lebih baik dari apa yang telah mereka

kerjakan".

Yang dimaksud dalam kehidupan yang baik pada ayat diatas adalah memperoleh rizki yang halal dan baik, pendapat lain mengatakan bahwa kehidupan yang baik adalah hari demi hari mendapat rizki dari Allah Swt.

Berdasarkan pada ayat 97 surat An-Nahl dapat disimpulkan bahwa kesejahteraan dapat diperoleh darimana siapa saja yang mau melakukan amal 
kebaikan. Oleh karena itu siapa saja yang melakukan amal kebaikan maka Allah Swt akan memberikan balasan berupa kehidupan yang lebih baik di dunia dan diakhirat dari apa yang telah dikerjakanya.

3) Kriteria Kesejahteraan

1. Indikator kesejahteran menurut Badan Pusat Statistik

Banyak teori untuk menilai kesejahteraan rakyat, konsepkesejahteraan dapat dirumuskan sebagai panduan maka darikonsep martabat manusia yang dapat dilihat dari empat indikator,

yaitu;

a) Rasa aman

b) Kesejahteraan

c) Kebebasan

d) Jati diri

Untuk memantau tingkat kesejahteraan masyarakat dalam suatu periode tertentu.Badan pusat statistik (BPS) melakukan Survey Social Ekonomi Nasional (susenas). Susenas mengambil informasi keadaan ekonomi masyarakat sebagai dasar untukmemperoleh indikator kesejahteraan. Adapun indicator kesejahteran menurut Badan Pusat Statistik sebagai berikut;

a) Jumlah dan pemerataan pendapatan hal ini berhubungandengan ekonomi. Pendapatan berhungan dengan lapanganpekerjaan, kondisi usaha, dan faktor ekonomi lainya. Penyediaan lapangan kerja mutlak dilakukan oleh semua pihak agar masyarakat memiliki pendapatan tetap untuk memenuhi kebutuhan hidupnya.

b) Kesehatan

Kualitas kesehatan yang semakin meningkat danmerata. Kesehatan merupakan faktor untuk mendapatkanpendapatan dan pendidikan, karena faktor kesehatanmerupakan hal yang paling utama.

c) Tingkat pendidikan

Kesejahteraan masyarakt tidak hanya dipandang dari segi ekonomi saja tetapi dari segi aspek lainya seperti pendidikan karena pindidikan merupakan cikal 
bakal dari terbentuknya kualitas sumber daya manusia yang handal. Dengan pendidikan yang baik maka akan melahirkan penerus bangsa yang kompeten. Oleh karena itu pendidikan merupakan factor penting dalam menggambarkan kondisi suatu masyarakat.

d) Ketenaga Kerjaan

Tenaga kerja merupakan modal bagi geraknya roda pembangunan. Kondisi jumlah komposisi tenaga kerjaakan terus mengalami perubahan seiring dengan berlangsungnya proses demografi. Indikator ketenagakerjaan salah satunya dapat diukur denganupah/gajih/pendapatan bersih. Melalui ukuran tersebut dapat digunakan untuk memenuhi kebutuhan baik itu kebutuhan primer atau sekunder yang dapat dijadikan tolak ukur layak atau tidak.

e) Perumahan dan lingkungan

Salah satu kebutuhan dasar bagi kehidupan manusia adalah adanya rumah tinggal. Keadaan perumahan yang baik dapat menunjang usaha pembangunan ekonomi. Karena dengan kualitas kehidupan yang layak melalui pemenuhan kebutuhan tempat tinggal akan terwujud kesejahteraan. Terwujudnya rumah yang layak huni adalah terjangkau dalam lingkungan yang sehat, aman terencana, dan berkelanjutan. Secara umum rumah tinggal yang dikategorikan dalam layak huni adalah rumah yang memiliki lantai, dinding dan atap yang memenuhi syarat.

f) Akses teknologi dan informasi

Merupakan salah satu hal yang dapat menarik untukmengetahui seberapa jauh perkembangan kesejahteraan dalam penguasaan/ kepemilikan akses teknologi daninformasi seperti penggunaan handphone atau pemeanfaatan computer dalam pengembangan bisnis.

\section{FAKTOR PENDUKUNG KESEJAHTERAAN}

Faktor pendukung dalam kesejahteraan suatu masyarakat yaitu dengan kemampuan desa yang mengurus dirinya sendiri dengan kekuatan yang dimiliki seperti: 
a. Pemanfaatan sumber daya alam dalam sektor potensial secara produktif, efesien dan efektif

b. Mendorong gerakan dan partisipasi masyarakat desa untuk membangun potensi guna kesejahteraan bersama.

c. Membangun kelembagaan ekonomi lokal yang produktif.

\section{KESIMPULAN}

Dapat diketahui bahwa peran ekonomi kreatif dalam meningkatkan kesejahteraan dilakukan melalui pola kekerabatan yaitu pola perekrutan karyawan yang dimulai dari kerabat terdekat dahulu dan warga atau masyarakat sekitar sehingga memberikan dampak positif. Karena bagi masyarakat selain mensejahterakan dengan mengurangi jumlah pengangguran usahan ini juga dapat meningkatkan pendapatan keluarga serta pendapatan masyarakat sekitar.

\section{DAFTAR PUSTAKA}

Alma Buchari, dan Doni Juni Priansa. Manajemen Bisnis Syariah. Cetakan ke-3. Bandung: Alfabeta, 2016.

Anoraga Pandji. Managemen Bisnis. Cetakan petama. Jakarta: PT Reneka Cipta,1997.

Assauri ofjan.Managemen Produksi Dan Operasi. Edisi 4.jakarta: Fakultas Ekonomi Universitas Indonesia, 1993.

Athoillah Anton. Dasar-Dasar Managemen.Cetakan ke 1. Bandung: CV Pustaka Setia, 2010.

Dermawan Deni. Metode Penelitian Kuantitatif. Cetakan ke tiga. Bandung: PT Remaja Rosdakarya, 2016.

Djamal M. Paradigma Penelitian Kualitatif. Cetakan ke-II Edisi Revisi. Yogyakarta: Mitra Pustaka, 2015.

Firdausy Carunia Mulya. Strategi Pengembang Ekonomi Kreatif di Indonesia. Cet-1. Jakarta: Yayasan Pustaka Obor Indinesia, 2017.

Hadi Sutrisno. Metodologi Research. Jilid 1. Yogyakarta: Yayasan Penerbitan Fakultas Psikologi Universitas Gajah Mada, 1984. 
Hasibuan Malayu S.P. Managemen: Dasar, Pengertian dan Masalah. Revisi, Cet.6. Jakarta: PT Bumi Aksara, 2007.

Hermanita.Perekonomian Indonesia. Yogyakarta: Idea Press, 2013.

https://amp.wartaekonomi.co.id/berita228758/upaya-dan-strategimewujudkandesa-sejahtera-mandiri.

Moeleong Lexy J..Metodologi Penelitian Kualitatif. Edisi revisi. Bandung: PT Remaja Rosdakarya, 2015.

Nitisusastro Mulyadi. Kewirausahaan dan Manajemen Usaha kecil.Cetakan ke-3. Bandung: Alfabeta, 2017.

Nugraha Firman, Mereka Yang Keluar: TKW Dan Perubahan Sosial Di Perdesaan, (Lekkas, 2018), 30-31

Sodiq Amirus. “Konsep Kesejahteraan dalam Islam.”Jurnal Ekonomi Syariah Vol.3, No.2 (2015): 383.

Soegoto Eddy Soeryanto. Enterpreneurship Menjadi Pembisnis Ulung. Cetakan ke2. Jakarta: PT Elex Media Komputindo, 2010.

Sugiyono.Metode Penelitian Bisnis. Edisi ke-3. Bandung: Alfabeta, 2017.

. Metode Penelitian Kuantitatif dan Kualitatif, dan R\&D. Cetakan ke-24. Bandung: Alfabeta, 2016. 